\title{
Analisis faktor-faktor yang mempengaruhi pertumbuhan ekonomi di Kabupaten Sarolangun
}

\author{
Rosminah*; Rahma Nurjanah; Etik Umiyati \\ Prodi Ekonomi Pembangunan Fak. Ekonomi dan Bisnis Universitas Jambi \\ *E-mail korespendensi: Rosminah035@gmail.com
}

\begin{abstract}
This study aims to determine how much influence labor, Domestic Investment (PMDN) and government expenditures have on economic growth in Sarolangun Regency. The type of data used is secondary data, namely time-series data for 2000-2017, in the form of data on economic growth, the number of workers, PMDN, and government contests. The analytical method used in this study is multiple linear regression or Ordinary Least Square (OLS). Results Based on the analysis shows that the workforce has a positive and significant effect on economic growth. PMDN has a positive and significant effect on economic growth. Likewise, government spending has a positive and significant effect on economic growth.
\end{abstract}

Keywords: Economic growth, Labor, Domestic investment (PMDN), Goverment expenditure.

\begin{abstract}
Abstrak
Penelitian ini bertujuan untuk mengetahui seberapa besar pengaruh tenaga kerja, Penanaman Modal Dalam Negeri (PMDN) dan pengeluaran pemerintah terhadap pertumbuhan ekonomi di Kabupaten Sarolangun. Jenis data yang digunakan adalah data sekunder yaitu berupa data time series tahun 2000-2017, berupa data pertumbuhan ekonomi, jumlah tenaga kerja, PMDN, dan pengeluaran pemerintah. Metode analisis yang digunakan dalam penelitian ini adalah regresi linear berganda atau Ordinary Least Square (OLS). Berdasarkan hasil analisis menunjukkan bahwa tenaga kerja berpengaruh positif dan signifikan terhadap pertumbuhan ekonomi. PMDN berpengaruh positif dan signifikan terhadap pertumbuhan ekonomi. Demikian pula pengeluaran pemerintah berpengaruh positif dan signifikan terhadap pertumbuhan ekonomi.
\end{abstract}

Kata kunci: Pertumbuhan ekonomi, Tenaga kerja, PMDN, Pengeluaran pemerintah.

\section{PENDAHULUAN}

Menurut Sukirno (2004) dalam analisis makro, tingkat pertumbuhan ekonomi yang dicapai oleh suatu negara diukur dari perkembangan pendapatan nasional riil yang dicapai suatu negara/daerah. Pertumbuhan ekonomi berarti perkembangan kegiatan dalam perekonomian yang menyebabkan barang dan jasa yang diproduksi dalam masyarakat bertambah dan kemakmuran masyarakat meningkat. Hal ini sejalan dengan Todaro (2000) yang menyatakan pertumbuhan ekonomi merupakan suatu proses peningkatan kapasitas produktif dalam suatu perekonomian secara terus menerus atau berkesinambungan sepanjang waktu sehingga menghasilkan tingkat pendapatan dan output nasional yang semakin lama semakin besar. Kemampuan yang meningkat ini disebabkan karena faktor- faktor produksi akan selalu mengalami pertambahan dalam 
jumlah dan kualitasnya. Dari segi investasi akan menambah jumlah barang modal yang akan digunakan pada masa yang akan datang agar produksi barang-barang dan jasa akan meningkat

Tabel 1. Pertumbuhan ekonomi Kabupaten Sarolangun Tahun 2013-2017 (persen)

\begin{tabular}{cc}
\hline Tahun & Pertumbuhan Ekonomi \\
\hline 2013 & 7,61 \\
2014 & 5,2 \\
2015 & 3,09 \\
2016 & 4,26 \\
2017 & 4,69
\end{tabular}

Sumber: Badan Pusat Statistik, Kabupaten Sarolangun dalam Angka 2018 (diolah)

Berdasarkan Tabel 1, pertumbuhan ekonomi di Kabupaten Sarolangun selama lima tahun terakhir mengalami fluktuasi. Pada tahun tahun 2013 pertumbuhan ekonomi di Kabupaten Sarolangun sebesar 7,61 persen. Pada tahun 2014 pertumbuhan ekonomi mengalami penurunan menjadi sebesar 5,2 persen. Pada tahun 2015 mengalami penurunan kembali menjadi sebesar 3,09 persen. Pada tahun 2016 pertumbuhan ekonomi mengalami peningkatan menjadi sebesar 4,26 persen. Pada tahun 2017 pertumbuhan ekonomi di Kabupaten Sarolangun meningkat kembali menjadi sebesar 4,69 persen.

Tenaga kerja juga merupakan suatu faktor yang mempengaruhi output suatu daerah. Partadiredja (2004) secara umum melihat tenaga kerja adalah sebagian dari penduduk yang berfungsi ikut serta dalam proses produksi dan menghasilkan barangbarang jasa. Disisi lain (Dumairy, 2001) mengartikan tenaga kerja adalah penduduk yang berumur dalam batas usia kerja. Batasan usia kerja berbeda-beda antara negara satu dengan yang lainnya. Senada dengan Dumairy, Tambunan (2004) mendefinisikan tenaga kerja adalah bagian dari penduduk (usia kerja), baik yang bekerja maupun yang mencari pekerjaan, yang masih mau dan mampu melakukan pekerjaan. Angkatan kerja yang besar akan terbentuk dari jumlah penduduk yang besar pula. Namun pertumbuhan penduduk yang besar dikhawatirkan akan menimbulkan efek yang buruk terhadap pertumbuhan ekonomi. Namun demikian penduduk yang cukup dengan tingkat pendidikan yang tinggi dan memiliki kemampuan atau skill akan mampu mendorong laju pertumbuhan ekonomi. Dari jumlah penduduk usia produktif yang besar maka akan mampu meningkatkam jumlah tenaga kerja dan angkatan kerja yang tersedia dan pada akhirnya akan mampu meningkatkan produksi output suatu daerah.

Tabel 2. Jumlah tenaga kerja Kabupaten Sarolangun Tahun 2013-2017 (jiwa)

\begin{tabular}{cc}
\hline Tahun & Tenaga Kerja \\
\hline 2013 & 120.786 \\
2014 & 121.238 \\
2015 & 130.586 \\
2016 & 135.578 \\
2017 & 139.970
\end{tabular}

Sumber: Badan Pusat Statistik, Kabupaten Sarolangun dalam Angka 2018 (diolah)

Bedasarkan Tabel 2, tenaga kerja di Kabupaten Sarolangun selama lima tahun terakhir mengalami peningkatan. Pada tahun 2013 tenaga kerja di Kabupaten Sarrolangun sebesar 120.786 jiwa. Pada tahun 2014 tenaga kerja meningkat menjadi 
sebesar 121.238 jiwa. Pada tahun 2015 tenaga kerja kembali mengalami peningkatan menjadi sebesar 130.586 jiwa. Pada tahun 2016 terus mengalami peningkatan menjadi sebesar 135.578 jiwa. Pada tahun 2017 meningkat kembali dari tahun sebelumnya menjadi sebesar 139.970 jiwa.

Upaya pemerintah untuk mewujudkan pertumbuhan ekonomi yang tinggi dalam pelaksanaannya selalu menemukan kendala, salah satunya ialah ketersediaan dana. Untuk itu pemerintah tarus berupaya untuk mewujudkan tingkat pertumbuhan ekonomi yang lebih baik dengan turut campur tangan melalui pengeluaran pemerintah. Menurut Suparmoko (2000), pengeluaran-pengeluaran pemerintah untuk jaminan sosial, pembayaran bunga dan bantuan pemerintah lainnya akan menambah pendapatan dan daya beli. Secara keseluruhan pengeluaran pemerintah ini akan memperluas pasaran hasil-hasil perusahaan dari industri yang pada gilirannya akan memperbesar pendapatan. Dengan bertambahnya pendapatan yang diperoleh pemerintah, maka akan mendorong pertumbuhan ekonomi.

Pengeluaran pemerintah selama lima tahun terakhir di Kabupaten Sarolangun mengalami peningkatan. Pada tahun 2013 pengeluaran pemerintah di Kabupaten Sarolangun sebesar Rp. 909.153.660.000, meningkat pada tahun 2014 menjadi sebesar Rp. 1.010.200.598.000. Pada tahun 2015 pengeluaran pemerintah meningkat menjadi sebesar Rp. 1.152.959.779.000 lalu meningkat di tahun 2016 menjadi sebesar Rp.1.189,629.244.000, kemudian pada tahun 2017 pengeluaran pemerintah meningkat dari tahun sebelumnya menjadi sebesar Rp.1.192.320.526.000 (BPS, 2018).

Faktor selanjutnya yang dapat memacu pertumbuhan ekonomi adalah investasi atau penanaman modal. Menurut Rahardja dan Manurung (2002), investasi adalah pengerluaran-pengeluaran yang meningkatkan jumlah barang modal (stok barang modal) dalam suatu perekonomian pada waktu tertentu. Semakin tinggi investasi maka akan semakin meningkatkan pertumbuhan ekonomi pada suatu daerah. Penanaman modal atau investasi ini sangat penting maka dari itu berbagai upaya harus dilakukan agar investor dari luar negeri dan dalam negeri tertarik dan berminat menanamkan modalnya serta mendorong berkembangnya investor dalam negeri. Investasi yang berfungsi untuk menambah kemampuan produksi barang dan jasa apabila mengalami peningkatan tentunya akan mendorong pertumbuhan ekonomi (Adrian dkk, 2007).

Tabel 3. Jumlah investasi PMDN Kabupaten Sarolangun Tahun 2000-2017 (ribu)

\begin{tabular}{cc}
\hline Tahun & Jumlah Investasi PMDN \\
\hline 2013 & $357.875,20$ \\
2014 & $432.764,59$ \\
2015 & $497.564,32$ \\
2016 & $576.579,93$ \\
2017 & $720.540,7$ \\
\hline
\end{tabular}

Sumber: Badan Pusat Statistik, Kabupaten Sarolangun dalam Angka 2018 (diolah)

Penanaman modal dalam negeri adalah penggunaan modal dalam negeri (yang merupakanlah bagian dari kekayaan masyarakat Indonesia termasuk hak-haknya dan benda-benda baik yang dimiliki oleh negara maupun swasta nasional atau swasta asing yang berdomisili di Indonesia yang disisihkan / disediakan guna menjalankan usaha) bagi usaha-usaha yang mendorong pembangunan ekonomi pada umumnya (Harjono,2007). Berdasarkan tabel 3, PMDN di Kabupaten Sarolangun selama lima tahun terakhir selalu mengalami peningkatan. Pada tahun 2013 PMDN di Kabupaten 
Sarolangun adalah sebesar Rp.357.875,20 ribu. Pada tahun 2014 PMDN mengalami peningkatan menjadi sebesar Rp.432.764,59 ribu. Pada tahun 2015 PMDN kembali meningkat menjadi sebesar Rp.497.564.,32 ribu. Pada tahun 2016 PMDN meningkat kembali menjadi sebesar Rp.576.579,93 ribu. Pada tahun 2017 PMDN meningkat dari tahun sebelumnya menjadi sebesar Rp. 720.540 ribu (BPS, 2018).

Berdasarkan uraian sebelumnya dapat diketahui bahwa jumlah tenaga kerja, pengeluaran pemerintah dan investasi di Kabupaten Sarolangun selalu mengalami peningkatan dari tahun 2013 hingga tahun 2017, tetapi dengan peningkatan tersebut ternyata pertumbuhan ekonomi Kabupaten Sarolangun mengalami fluktuasi, padahal seharusnya dengan meningkatnya berbagai faktor tadi, laju pertumbuhan ekonomi meningkat setiap tahunnya. Berdasarkan latar belakang tersebut, penelitian ini bertujuan untuk menganalisis: 1) perkembanga tenaga kerja, PMDN, pengeluaran pemerintah dan pertumbuhan ekonomi. 2) pengaruh tenaga kerja, PMDN dan pengeluaran pemerintah terhadap pertumbuhan ekonomi.

\section{METODE}

Penelitian ini menggunakan data sekunder, dalam bentuk data runtut waktu (time series) yang diperoleh dari publikasi Badan Pusat Statistik (BPS) Provinsi Jambi. Data yang digunakan berupa Pertumbuhan Ekonomi (PE), Tenaga Kerja (TK), Penanaman Modal Dalam Negeri (PMDN), Pengeluaran Pemerintah (PP) di Kabupaten Sarolangun. Metode yang digunakan dalam penelitianini yaitu metode deskriptif untuk melihat perkembangan tenaga kerja, PMDN, pengeluaran pemerintah dan pertumbuhan ekonomi. Kemudian menggunakan analisis regresi linear berganda untuk menganalisis pengaruh tenaga kerja, PMDN, pengeluaran pemerintah tergadap pertumbuhan ekonomi dengan menggunakan model sebagai berikut (Gujarati, 2003):

$$
Y=\beta_{0}+\beta_{1} X_{1}+\beta_{2} X_{2}+\beta_{3} X_{3}+\varepsilon
$$

Selanjutnya formulasi tersebut ditransformasikan dalam bentuk logaritma sebagai berikut :

Keterangan :

$$
\mathrm{PE}=\beta_{0}+\beta_{1} \log \mathrm{TK}+\beta_{2} \log \mathrm{PMDN}+\beta_{3} \log \mathrm{PP}+\varepsilon
$$

$\begin{array}{llll}\mathrm{PE} & =\text { Pertumbuhan ekonomi (persen) } & \beta_{\circ} & =\text { Konstanta regresi } \\ \mathrm{TK} & =\text { Tenaga kerja (jiwa) } & \beta_{1}, \beta_{2}, \beta_{3}, & =\text { Koefesien regresi } \\ \mathrm{PMDN} & =\text { Investasi PMDN (ribu rupiah) } & \varepsilon & =\text { Kesalahan } \\ \mathrm{PP} & =\text { Pengeluaran pemerintah (rupiah) } & & \text { Pengganggu }\end{array}$

\section{Pengujian hipotesis}

$\mathbf{U j i}-\mathbf{F}$

Uji ini pada dasarnya untuk menunjukkan apakah semua variabel bebas yang dimasukkan dalam model mempunyai pengaruh secara bersama-sama terhadap variabel terikat dengan cara:

a. Menentukan hipotesis yang akan diuji (Ho dan Ha)

b. Menentukan level of significance $(\alpha)$ tertentu

c. Menentukan kriteria pengujian dengan membandingkan nilai F-tabel dan F-hitung

d. Menarik kesimpulan. 
Apabila F-hit lebih besar daripada F-tabel maka Ho ditolak, artinya variabel bebas secara bersama-sama mempengaruhi variabel tidak bebas. Nilai F-hit dicari dengan cara sebagai berikut: (Gujarati, 2003)

Dimana:

$$
F-\text { hitung }=\frac{R^{2} /(k-1)}{\left(1-R^{2}\right) /(n-k)}
$$

$\mathrm{R}^{2}=$ koefisien determinasi

$\mathrm{k}=$ jumlah variabel bebas

$\mathrm{n}=$ jumlah observas

Maka dengan derajat tertentu :

F- hitung < F- table, Maka Ho yang diterima artinya secara bersama-sama variabel independen secara signifikan tidak di pengaruhi variabel dependen. F- hitung > F- table, Maka Ho yang diterima artinya secara bersama-sama variabel independen secara signifikan di pengaruhi variabel dependen.

Uji- t

Pengujian tingkat significant dari masing-masing koefesien dari masing-masing regresi digunakan Uji-t test yaitu (Gujarati, 2003) :

Dimana:

$$
t-{ }_{\text {hitung }}=\frac{\beta i}{S E(\beta i)}
$$

$b i=$ nilai koefisien regresi

$S E=$ nilai standar error dari $b i$

Dengan derajat keyakinan tertentu, maka jika :

- t- hitung < t table, Maka Ho diterima dan Ha di tolak, artinya secara individu tidak ada pengaruh yang berarti antara variable independent terhadap variable dependen

- t- hitung > t table, Maka Ho di tolak dan Ha di terima, artinya secara individu ada pengaruh yang berarti antara variable independent terhadap variable dependen

\section{Koefesien determinasi $\left(\mathbf{R}^{2}\right)$}

Koefisien determinasi ini mengukur seberapa jauh kemampuan model dalam menerangkan variasi variabel terikat. Koefisien ini nilainya antara nol (0) sampai dengan satu (1). Semakin besar nilai koefisien tersebut maka variabel-variabel bebas lebih mampu menjelaskan variasi variabel terikatnya. Untuk menghitung besarnya determinan $\left(\mathrm{R}^{2}\right)$ dapat digunakan rumus sebagai berikut (Gujarati, 2003):

$$
R^{2}=\frac{E S S}{T S S}=1-\frac{R^{2} /(k-1)}{\left(1-R^{2}\right) /(n-k)}
$$

Dimana:

$\mathrm{R}^{2}=$ koefisien determinasi $\mathrm{n} \quad=$ Jumlah observasi

$\mathrm{ESS}=$ Jumlah kuadrat residual $\mathrm{K}=$ Jumlah parameter

TSS $=$ Total jumlah kuadrat residual (termasuk intersep)

\section{Uji asumsi klasik}

Analisis regresi linier, seringkali ditemukan permasalahan yang terdapat dalam model yang telah dibuat. Hal ini dapat menyebabkan kesalahan dalam interpretasi data yang pada akhirnya juga berpengaruh pada kebenaran dari hasil analisis. Untuk itu, 
perlu dilakukan pengujian terhadap model regresi yang telah dibuat, agar model yang dibuat dapat memenuhi sifat BLUE (best linier unbiased estimator). Ada beberapa jenis uji yang harus dilakukan sebelum hasil analisis diinterpretasikan, yaitu uji normalitas, uji multikolinieritas, uji heteroskedastisitas, dan ujiautokorelasi.

\section{Uji normalitas}

Uji normalitas digunakan untuk menentukan apakah data yang telah dikumpulkan berdistribusi normal atau diambil dari populasi normal. Uji normalitas juga melihat apakah model regresi yang digunakan sudah baik. Model regresi yang baik adalah memiliki distribusi data normal atau mendekati normal (Ghozali, 2011). Dalam penelitian ini uji normalitas menggunakan Kolmogorov-Smirnov. Dasar pengambilan keputusan adalah melihat angka probabilitas, dengan ketentuan:

Probabilitas $>0,05$ : hipotesis diterima karena data berdistribusi secara normal

Probabilitas $<0,05:$ hipotesis ditolak karena data tidak berdistribusi normal.

\section{Uji multikolinieritas}

Hubungan linier antara variable independen dalam regresi berganda disebut multikolinieritas. Uji multikolinearitas bertujuan menguji apakah dalam regresi ditemukan adanya korelasi antar variable bebas (independen). Model regresi yang baik seharusnya tidak mengandung korelasi di antara variabel-variabel independen. Pendeteksian keberadaan multikolinearitas dapat dilihat dari nilai tolerance dan lawannya Variance Inflation Factor (VIF). Kedua ukuran ini menunjukkan variable independen manakah yang dijelaskan oleh variable independen lainnya. Apabil anilai tolerance di atas 10 persen dan VIF di bawah 10, maka dapat disimpulkan bahwa model regresi bebas dari multikolinearitas (Widarjono, 2009).

\section{Uji autokorelasi}

Auto korelasi merupakan korelasi antar satu variabel gangguan dengan variabel gangguan yang lain. Adanya autokorelasi dalam model regresi akan mengakibatkan model regresi tersebut memiliki karakteristik sebagai berikut (Widarjono, 2009). Terdiri dari: 1).Estimator atau model masih linier. 2).Estimator atau model masih tidak bias. 2).Meskipun demikian, estimator atau model tidak lagi memiliki varian yang minimum (no longer best).

Dengan adanya autokorelasi dalam model regresi, model yang dihasilkan tidak memiliki sifat BLUE, namun hanya LUE. Jika estimator atau model tidak mempunyai varian yang minimum maka memiliki konsekuensi sebagai berikut (Widarjono, 2009) terdiri dari: 1).Jika varian tidak minimum maka menyebabkan perhitungan standar error tidak lagi bisa dipercaya kebenarannya. 2).Selanjutnya interval estimasi maupun uji hipotesis yang didasarkan pada distribusi $t$ maupun $\mathrm{F}$ tidak lagi bisa dipercaya untuk evaluasi hasil regresi.

Metode yang biasa digunakan untuk mendeteksi adanya autokorelasi adalah metode Durbin Watson dengan ketentuan sebagaimana dapat dilihat pada Gambar 1. Jika nilai Durbin Watson (DW) lebih kecil dari dL atau lebih besar dari 4-dL maka hipotesis nol ditolak, yang berarti terdapat autokorelasi. Jika nilai DW terletak antara dU dan 4-dU, maka hipotesis nol diterima, yang berarti tidak ada autokorelasi. Jika nilai DW terletak antara dL dan dU atau diantara 4-dU dan 4-dL, maka tidak menghasilkan kesimpulan yang pasti. Nilai dUdan dL dapat diperoleh dari tabel statistik Durbin Watson yang bergantung banyaknya observasi dan banyaknya variabel yang menjelaskan. 


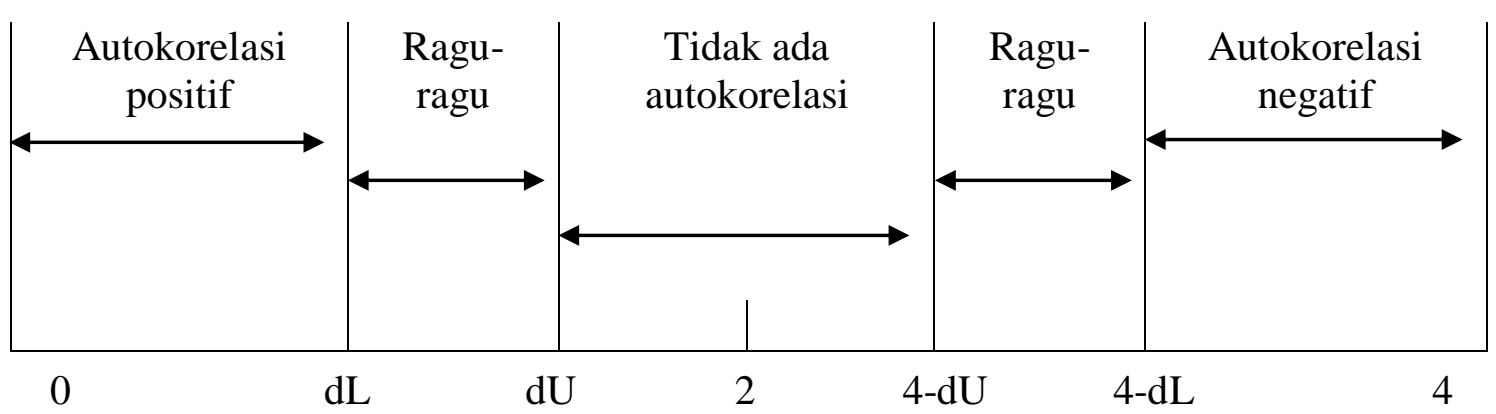

Gambar 1. Statistik Durbin Watson

\section{Uji heteroskedastisitas}

Uji heteroskedastisitas bertujuan menguji apakah dalam regresi terjadi ketidaksamaan varians dari residual satu pengamatan kepengamatan yang lain. Jika varians dari residual satu pengamatan kepengamatan yang lain tetap, maka disebut homoskedastisitas dan jika berbeda disebut heteroskedastisitas. Model regresi yang baik adalah yang homoskedastisitas atau yang tidak terjadi heteroskedastisitas. Untuk mendeteksi ada tidaknya heteroskedastisitas dapat dilakukan dengan melihat grafik plot antara nilai prediksi variable dependen (ZPRED) dengan residualnya(SRESID). Apabila ada pola tertentu, seperti titik-titik yang ada membentuk pola tertentu yang teratur (bergelombang, melebar kemudian menyempit), maka mengindikasikan telah terjadi heteroskedastisitas (Widarjono, 2009).

\section{HASIL DAN PEMBAHASAN}

\section{Perkembangan PDRB}

Salah satu cara untuk melihat kemajuan ekonomi suatu daerah adalah dengan melihat perkembangan PDRB-nya. Perhitungan harga konstan berguna untuk melihat pertumbuhan ekonomi secara keseluruhan atau sektoral. Juga untuk melihat perubahan struktur perekonomian dari tahun ketahun.

Tabel 4. Perkembangan PDRB Kabupaten Sarolangun atas dasar harga konstan Tahun 2000 Periode 2000-2017

\begin{tabular}{ccc}
\hline Tahun & PDRB (Juta) & Laju Pertumbuhan $(\boldsymbol{\%})$ \\
\hline 2000 & 630.836 & - \\
2001 & 680.907 & 7,94 \\
2002 & 708.850 & 5,8 \\
2003 & 757.755 & 5,19 \\
2004 & 802.290 & 5,88 \\
2005 & 845.331 & 5,36 \\
2006 & 953.277 & 7,82 \\
2007 & 977.702 & 7,27 \\
2008 & 1.055 .112 & 7,62 \\
2009 & 1.139 .442 & 7,99 \\
2010 & 1.232 .587 & 8,09 \\
2011 & 1.339 .988 & 8,8 \\
2012 & 1.454 .521 & 8,49 \\
2013 & 1.569 .330 & 7,61 \\
2014 & 1.696 .727 & 5,2 \\
2015 & 1.705 .642 & 3,09 \\
2016 & 1.778 .349 & 4,26 \\
2017 & 1.860 .742 & 4,69 \\
\hline
\end{tabular}

Sumber: Badan Pusat Statistik, Sarolangun (diolah) 
Berdasarkan Tabel 4, dapat dilihat PDRB Kabupaten Sarolangun ADHK tahun 2000 periode 2000-2017 selalu mengalami peningkatan dari tahun ke tahun, tetapi dengan laju pertumbuhan yang cenderung fluktuatif. Secara rata-rata laju pertumbuhan PDRB adalah sebesar 6,56 persen. Laju pertumbuhan tertinggi terjadi pada tahun 2011 yang mencapai 8,8 persen dengan total PDRB sebesar 1.339 .988 juta meningkat dari tahun 2010 dengan total PDRB sebesar 1.232.587 rupiah. Kemudian, laju pertumbuhan ekonomi terendah terjadi pada tahun 2015 yaitu 3,09 persen dengan total PDRB berjumlah 1.705.642 juta meningkat dari tahun 2014 dengan total PDRB sebesar 1.696.727 juta.

Pada Tabel 4 di atas dapat terlihat bahwa laju pertumbuhan ekonomi cenderung fluktuatif, dengan rata-rata pertumbuhan sebesar 6,56 persen. Pertumbuhan ekonomi terendah terjadi pada tahun 2015 yaitu sebesar 3,09. Pertumbuhan ekonomi tertinggi terjadi di tahun 2011 yang mencapai 8,8 persen, ini dikarenakan seluruh faktor-faktor produksi yang membentuk PDRB meningkat sangat baik sehingga pertumbuhan ekonomi tinggi.

\section{Perkembangan tenaga kerja}

Tenaga kerja sebagai penunjang proses output dalam kegiatan produksi, jumlah tenaga kerja yang lebih besar berarti akan menambah jumlah tenaga kerja produktif. Dengan demikian meningkatnya jumlah tenaga kerja di suatu daerah diasumsikan mampu menunjang laju pertumbuhan ekonomi di daerah tersebut khususnya di Kabupaten Sarolangun.

Tabel 5. Perkembangan tenaga kerja di Kabupaten Sarolangun Tahun 2000-2017.

\begin{tabular}{ccc}
\hline Tahun & Tenaga Kerja (Jiwa) & Perkembangan $(\%)$ \\
\hline 2000 & 80.160 & - \\
2001 & 80.959 & 1,00 \\
2002 & 81.828 & 1,07 \\
2003 & 82.675 & 1,04 \\
2004 & 83.529 & 1,03 \\
2005 & 84.395 & 1,04 \\
2006 & 85.547 & 1,37 \\
2007 & 87.664 & 2,47 \\
2008 & 88.759 & 1,25 \\
2009 & 91.447 & 3,03 \\
2010 & 98.917 & 8,17 \\
2011 & 111.840 & 13,06 \\
2012 & 115.517 & 3,29 \\
2013 & 120.786 & 4,56 \\
2014 & 121.238 & 0,37 \\
2015 & 130.586 & 7,71 \\
2016 & 135.578 & 3,82 \\
2017 & 139.970 & 3,24 \\
\hline \multicolumn{3}{c}{}
\end{tabular}

Sumber: Badan Pusat Statistik Kabupaten Sarolangun (diolah)

Berdasarkan Tabel 5, dari tahun 2000 hingga tahun 2017 jumlah tenaga kerja di Kabupaten Sarolangun terus mengalami peningkatan dengan rata-rata sebesar 3,20 persen. Tahun 2001 tenaga kerja naik sebesar 1 persen, yaitu dari 80.160 jiwa pada tahun 2000 menjadi 80.959 jiwa di tahun 2001. Tahun 2002 jumlah tenaga kerja kembali meningkat sebesar 1,07 persen atau menjadi 81.828 jiwa, kemudian terus 
meningkat hingga tahun 2017 menjadi 139.970 jiwa. Jumlah tenaga kerja di Kabupaten Sarolangun selalu meningkat dari tahun ke tahun, dengan perkembangan yang cenderung fluktuatif. Rata-rata perkembangan tenaga kerja di Kabupaten Sarolangun adalah 3,20 persen. Perkembangan tertinggi terjadi pada tahun 2011 yaitu sebesar 13,06 persen dengan jumlah tenaga kerja sebanyak 111.840 jiwa, meningkat dari tahun 2010 dengan jumlah tenaga kerja sebanyak 98.917 jiwa. Kemudian perkembangan terendah terjadi pada tahun 2014 yaitu 0,37 persen dengan jumlah tenaga kerja sebanyak 121.238 jiwa, meningkat dari tahun 2013 dengan jumlah tenaga kerja sebanyak 120.786 jiwa.

\section{Perkembangan PMDN}

Penanaman modal merupakan sektor utama yang sangat berpengaruh dalam menggerakkan roda perekonomian. Penanaman modal dalam negeri dapat berperan dalam pembangunan ekonomi, meningkatkan produksi, memberi perluasan kesempatan kerja, mengolah sumber-sumber potensi ekonomi di dalam negeri. Penanaman modal dalam negeri juga diharapkan dapat pula ikut berperan dalam meningkatkan taraf hidup masyarakat dan pembangunan ekonomi pada umumnya.

Tabel 6. Perkembangan PMDN Kabupaten Sarolangun Tahun 2000- 2017

\begin{tabular}{crr}
\hline Tahun & Jumlah Investasi PMDN (ribu) & Perkembangan $\mathbf{( \% )}$ \\
\hline 2000 & 614.880 & - \\
2001 & $384.546,2$ & $-37,5$ \\
2002 & 354.057 & $-7,9$ \\
2003 & 354.057 & 0,0 \\
2004 & 354.958 & 0,3 \\
2005 & 353.521 & $-0,4$ \\
2006 & $354.057,29$ & 0,2 \\
2007 & $374.057,28$ & 5,6 \\
2008 & $355.167,26$ & $-5,1$ \\
2009 & $265.301,26$ & $-25,3$ \\
2010 & $175.403,26$ & $-33,9$ \\
2011 & $216.238,27$ & 23,3 \\
2012 & $247.301,19$ & 14,4 \\
2013 & $247.301,19$ & 0,0 \\
2014 & 371.955 & 50,4 \\
2015 & $373.655,81$ & 0,5 \\
2016 & $576.579,93$ & 54,3 \\
2017 & $720.540,7$ & 25,0 \\
\hline
\end{tabular}

$\frac{\text { Rata-rata }}{\text { Sumber: Badan Pusat Statistik Kabupaten Sarolangun (diolah) }}$

Berdasarkan Tabel 6, dapat dilihat bahwa investasi PMDN Kabupaten Sarolangun dari tahun 2000-2017 mengalami fluktuasi, dengan rata-rata perkembangan sebesar 9,35 persen. Penurunan PMDN tertinggi terjadi pada tahun 2001 yaitu sebesar 37,5 persen dengan total PMDN sebesar 384.546,2 rupiah. Perkembangan PMDN tertinggi terjadi pada tahun 2016 yaitu sebesar 54,3 persen dengan total PMDN sebesar 576.579,93 rupiah, naik dari tahun 2015 yang berjumlah 373.655,81 rupiah. Kenaikan PMDN yang tinggi ini bisa jadi disebabkan karena berhasilnya pemerintah Kabupaten 
Sarolangun dalam menarik investor-investor agar menanamkan modalnya di berbagai sektor Kabupaten Sarolangun, apalagi didukung pemerintah pusat yang sudah mengeluarkan paket kebijakan yang memudahkan investor untuk menanamkan modalnya.

\section{Perkembangan pengeluaran pemerintah}

Pemerintah tarus berupaya untuk mewujudkan tingkat pertumbuhan ekonomi yang lebih baik dengan turut campur tangan melalui pengeluaran pemerintah. Pertumbuhan ekonomi diduga sangat erat kaitannya dengan jumlah investasi dan pengeluaran pemerintah. Pengeluaran pemerintah yang terlalu kecil akan merugikan tingkat pertumbuhan ekonomi, pengeluaran pemerintah yang proposional akan meningkatkan pertumbuhan ekonomi dan pengeluaran konsumsi yang boros akan menghambat pertumbuhan ekonomi.

Tabel 7. Perkembangan pengeluaran pemerintah di Kabupaten Sarolangun Tahun 2000-2017.

\begin{tabular}{ccc}
\hline Tahun & Pengeluaran Pemerintah (Rp) & Perkembangan (\%) \\
\hline 2000 & 94.223 .890 .717 & - \\
2001 & 96.658 .028 .353 & 2,58 \\
2002 & 145.015 .187 .014 & 50,03 \\
2003 & 164.786 .700 .027 & 13,63 \\
2004 & 174.082 .900 .838 & 5,64 \\
2005 & 211.751 .755 .332 & 21,64 \\
2006 & 256.241 .924 .636 & 21,01 \\
2007 & 390.950 .328 .145 & 52,57 \\
2008 & 591.636 .322 .495 & 51,33 \\
2009 & 554.910 .397 .217 & $-6,21$ \\
2010 & 615.345 .120 .328 & 10,89 \\
2011 & 634.977 .334 .204 & 3,19 \\
2012 & 724.384 .556 .088 & 14,08 \\
2013 & 777.889 .112 .446 & 7,39 \\
2014 & 841.835 .223 .567 & 8,22 \\
2015 & 838.422 .624 .030 & $-0,41$ \\
2016 & 941.701 .156 .904 & 12,32 \\
2017 & 919.187 .309 .009 & $-2,39$ \\
\hline
\end{tabular}

Sumber: Badan Pusat Statistik Kabupaten Sarolangun (diolah)

Berdasarkan Tabel 7, dapat dilihat pengeluaran pemerintah Kabupaten Sarolangun mengalami fluktuasi namun cenderung naik. Rata-rata pengeluaran pemerintah Kabupaten Sarolangun adalah sebesar 14,75 persen dari tahun 2000 hingga tahun 2017. Perkembangan pengeluaran pemerintah tertinggi terjadi pada tahun 2007 yaitu sebesar 52,57 persen dengan total pengeluaran sebanyak 390.950.328.145 rupiah yang naik dari tahun 2006 dengan total pengeluaran sebesar 256.241.924.636 rupiah, sedangkan kenaikan terendah terjadi pada tahun 2001 yaitu sebesar 2,58 persen dengan total pengeluaran sebesar 96.658.028.353 rupiah. Selain mengalami kenaikan, pengeluaran pemerintah Kabupaten Sarolangun juga mengalami penurunan di beberapa tahun, yaitu di tahun 2009, tahun 2015 dan tahun 2017, dengan penurunan berturut-turut yaitu 6,21 
persen, 0,41 persen, dan 2,39 persen. Penurunan tersebut bisa jadi disebabkan karena keterlambatan pada sisi perencanaan.

Pengaruh tenaga kerja, PMDN dan pengeluaran pemerintah terhadap pertumbuhan ekonomi Kabupaten Sarolangun

Berdasarkan hasil perhitungan dengan menggunakan bantuan program Eviews 8.0, maka diperoleh hasil estimasi persamaan regresi linear sederhana dengan model Fixed Effect sebagai berikut:

Tabel 8. Hasil regresi

\begin{tabular}{lrlcl}
\hline \multicolumn{1}{c}{ Variable } & Coefficient & Std. Error & t-Statistic & Prob. \\
\hline C & 21.32565 & 19.08216 & 1.117570 & 0.2826 \\
LOG(TK) & 9.860529 & 2.192133 & 4.498145 & 0.0005 \\
LOG(PMDN) & 1.631326 & 0.561278 & 2.906452 & 0.0115 \\
LOG(PP) & 2.916796 & 0.673931 & 4.328033 & 0.0007 \\
\hline R-squared & 0.635494 & Mean dependent var & 6.558333 \\
Adjusted R-squared & 0.557386 & S.D. dependent var & 1.654528 \\
S.E. of regression & 1.100745 & Akaike info criterion & 3.222982 \\
Sum squared resid & 16.96295 & Schwarz criterion & 3.420842 \\
Log likelihood & -25.00683 & Hannan-Quinn criter. & 3.250264 \\
F-statistic & 8.136054 & Durbin-Watson stat & 1.919594 \\
Prob(F-statistic) & 0.002216 & & \\
\hline Sumber: Datadion & &
\end{tabular}

Sumber: Data diolah, 2019

Berdasarkan hasil regresi pada Tabel 8, maka diperoleh persamaan regresi sebagai berikut:

$\mathrm{PE}=21.32565+9.860529 \mathrm{LOG} \mathrm{TK}+1.631326 \mathrm{LOG} \mathrm{PMDN}+2.916796 \mathrm{LOG} \mathrm{PP}+\varepsilon$

\section{Uji F}

Uji $\mathrm{F}$ digunakan untuk mengetahui apakah variabel independen berpengaruh signifikan terhadap variabel dependen secara simultan. Dengan demikian berlaku pengujian sebagai berikut :

$\mathrm{H}_{0}$ ditolak jika F-stat > F-tabel, ini berarti bahwa variabel bebas (Tenaga Kerja, PMDN, Pengeluaran Pemerintah) berpengaruh signifikan terhadap variabel terikat (Pertumbuhan Ekonomi).

$\mathrm{H}_{1}$ diterima jika F-stat < F-tabel, ini berarti bahwa variabel bebas (Tenaga Kerja, PMDN, Pengeluaran Pemerintah) tidak berpengaruh signifikan terhadap variabel terikat (Pertumbuhan Ekonomi).

Hasil uji F dapat dilihat pada tabel di atas. Nilai prob. F (Statistic) sebesar 0.002216 lebih kecil dari tingkat signifikansi 0,05 sehingga dapat disimpulkan bahwa model regresi yang diestimasi layak digunakan untuk menjelaskan pengaruh Tenaga Kerja (TK), PMDN, dan pengeluaran pemerintah (PP) terhadap Pertumbuhan Ekonomi (PE).

\section{Uji t}

\section{Variabel tenaga kerja (TK)}

Dari hasil regresi pada tabel 8 , dapat dilihat nilai prob. t hitung dari variabel bebas Log TK sebesar 0.0005 yang lebih kecil dari 0,05 sehingga variabel bebas Log 
TK berpengaruh signifikan terhadap variabel terikat PE pada alpha 5\% atau dengan kata lain, tenaga kerja berpengaruh signifikan terhadap perumbuhan ekonomi pada taraf keyakinan $95 \%$.

\section{Variabel penanaman modal dalam negeri (PMDN)}

Dari hasil regresi pada tabel 8 , dapat dilihat nilai prob. $t$ hitung dari variabel bebas Log PMDN sebesar 0.0115 yang lebih kecil dari 0,05 sehingga variabel bebas Log PMDN berpengaruh signifikan terhadap variabel terikat PE pada alpha 5\% atau dengan kata lain, PMDN berpengaruh signifikan terhadap perumbuhan ekonomi pada taraf keyakinan $95 \%$.

\section{Variabel pengeluaran pemerintah (PP)}

Dari hasil regresi pada tabel 8 , dapat dilihat nilai prob. $t$ hitung dari varoabel bebas Log PP sebesar 0.0007 yang lebih kecil dari 0,05 sehingga dapat dikatakan bahwa variabel bebas Log PP berpengaruh signifikan terhadap variabel terikat PE pada alpha 5\% atau dengan kata lain, pengeluaran pemerintah berpengaruh signifikan terhadap pertumbuhan ekonomi pada taraf keyakinan $95 \%$.

\section{Koefisien determinasi $\left(\mathbf{R}^{2}\right)$}

Koefisien determinasi $\left(\mathrm{R}^{2}\right)$ menjelaskan variasi pengaruh variabel-variabel bebas terhadap variabel terikatnya. Atau dapat pula dikatakan sebagai proporsi pengaruh seluruh variabel bebas terhadap variabel terikat. Nilai koefisien determinasi dapat diukur oleh nilai R-Square atau Adjusted R-Square. R-Square digunakan pada saat variabel bebas hanya 1 saja (biasa disebut dengan Regresi Linier Sederhana), sedangkan Adjusted R-Square digunakan pada saat variabel bebas lebih dari satu. Dalam menghitung nilai koefisien determinasi penulis lebih senang menggunakan R-Square daripada Adjusted R-Square, walaupun variabel bebas lebih dari satu.

Nilai R-Square pada tabel di atas besarnya 0.635494 menunjukkan bahwa proporsi pengaruh variabel Log TK, Log PMDN dan Log PP terhadap variabel PE sebesar $63,54 \%$. Artinya, tenaga kerja, PMDN, dan pengeluaran pemerintah memiliki proporsi pengaruh terhadap pertumbuhan ekonomi sebesar $63,54 \%$, sedangkan sisanya $36,46 \%$ dipengaruhi oleh variabel lain yang tidak ada di dalam model regresi.

\section{Uji asumsi klasik}

Hipotesis dalam penelitian ini diuji dengan menggunakan teknik analisis regresi linier berganda. Tujuannya adalah untuk mengetahui ada tidaknya pengaruh signifikan antara satu atau lebih variabel bebas $(\mathrm{X})$ terhadap variabel terikat $(\mathrm{Y})$ baik secara parsial maupun berganda (simultan) (Sunyoto, 2011). Sebelum data dianalisis, terlebih dahulu dilakukan uji asumsi klasik yang terdiri dari uji normalitas, mulitikolinearitas, autokorelasi, dan heteroskedastisitas.

\section{Uji normalitas}

Uji normalitas bertujuan untuk menguji apakah dalam model regresi, variabel atau residual memiliki distribusi normal, dengan hipotesis :

$\mathrm{H}_{0}$ : data tidak terdistribusi secara normal

$\mathrm{H}_{1}$ : data terdistribusi secara normal 
Keputusan terdistribusi normal tidaknya residual secara sederhana dengan membandingkan nilai Probabilitas JB (Jarque-Bera) hitung dengan tingkat alpha 0,05 (5\%). Apabila Prob. JB hitung lebih besar dari 0,05 maka dapat disimpulkan bahwa residual terdistribusi normal dan sebaliknya, apabila nilainya lebih kecil maka tidak cukup bukti untuk menyatakan bahwa residual terdistribusi normal. Nilai Prob. JB hitung sebesar $1.550681>0,05$ sehingga dapat disimpulkan bahwa residual terdistribusi normal yang artinya asumsi klasik tentang kenormalan telah dipenuhi.

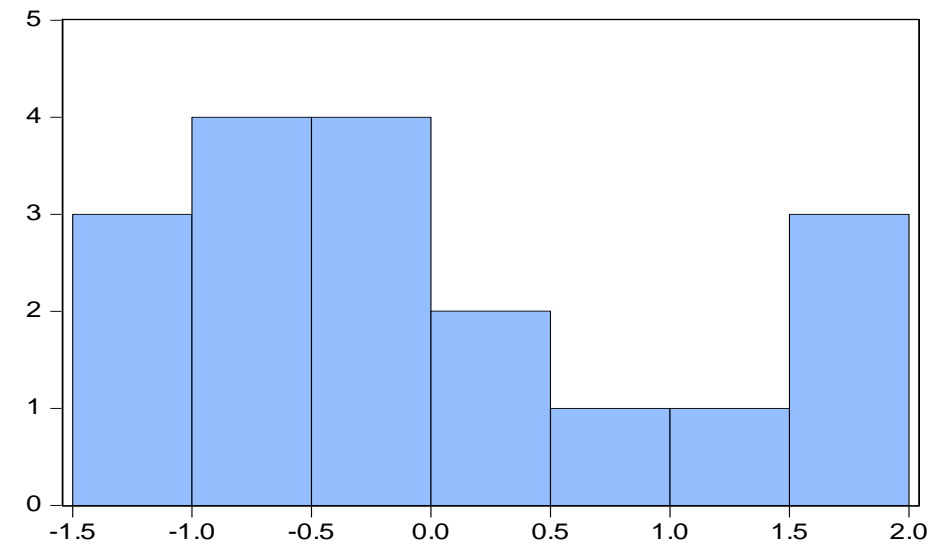

\begin{tabular}{|lc|}
\hline \multicolumn{2}{|l|}{ Series: Residuals } \\
Sample 2000 2017 \\
Observations & 18 \\
& \\
Mean & 5.51 e-15 \\
Median & -0.251310 \\
Maximum & 1.716111 \\
Minimum & -1.462231 \\
Std. Dev. & 0.998910 \\
Skewness & 0.509692 \\
Kurtosis & 1.985884 \\
& \\
Jarque-Bera & 1.550681 \\
Probability & 0.460547 \\
\hline
\end{tabular}

Sumber: Data diolah, 2019

Gambar 1. Hasil uji normalitas

\section{Uji multikolinearitas}

Menurut Ghozali (2011), uji multikolinieritas bertujuan untuk menguji apakah model regresi ditemukan adanya korelasi atas variabel bebas (independen). Model regresi yang baik seharusnya bebas multikolinieritas atau tidak terjadi korelasi di antara variabel independen. Untuk mendeteksi ada atau tidaknya masalah multikolinieritas dalam penelitian ini adalah dengan melihat nilai Variance Inflation Factor (VIF).

Tabel 9. Hasil uji multikolinearitas

\begin{tabular}{cccc}
\hline \multirow{2}{*}{ Variable } & $\begin{array}{c}\text { Coefficient } \\
\text { Variance }\end{array}$ & $\begin{array}{c}\text { Uncentered } \\
\text { VIF }\end{array}$ & $\begin{array}{c}\text { Centered } \\
\text { VIF }\end{array}$ \\
\hline C & 364.1288 & 5409.462 & NA \\
LOG(TK) & 4.805445 & 9452.817 & 2.685622 \\
LOG(PMDN) & 0.315032 & 786.9673 & 1.431341 \\
LOG(PP) & 0.454183 & 4772.646 & 3.358097 \\
\hline
\end{tabular}

Sumber: Data diolah, 2019

Hasil uji multikolinieritas, dapat dilihat pada Tabel 9 kolom Centered VIF. Nilai VIF untuk variabel TK, PMDN dan PP yaitu berturut-turut 2.685633, 1.431341 dan 3.358097. Karena nilai VIF dari ketiga variabel tidak ada yang lebih besar dari 10 atau 5 (banyak buku yang menyaratkan tidak lebih dari 10, tapi ada juga yang menyaratkan tidak lebih dari 5) maka dapat dikatakan tidak terjadi multikolinieritas pada kedua variabel bebas tersebut. Berdasarkan syarat asumsi klasik regresi linier dengan OLS, 
maka model regresi linier yang baik adalah yang terbebas dari adanya multikolinieritas. Dengan demikian, model di atas telah terbebas dari adanya multikolinieritas.

\section{Uji autokorelasi}

Uji Autokorelasi bertujuan untuk mengetahui apakah dalam model regresi linear ada korelasi antara kesalahan penganggu pada periode t-1. Apabila terdapat korelasi maka ada auto korelasi. Autokorelasi muncul karena observasi yang berurutan sepanjang waktu berkaitan satu sama lainnya. Uji autokorelasi dalam penelitian ini dengan menggunakan metode Brusch-Godfrey atau LM (Lagrange Multiplier) test.

Tabel 10. Hasil uji autokorelasi

\section{Breusch-Godfrey Serial Correlation LM Test:}

\begin{tabular}{llll} 
F-statistic & 0.950132 & Prob. F(2,12) & 0.4140 \\
Obs*R-squared & 2.460727 & Prob. Chi-Square(2) & 0.2922 \\
\hline
\end{tabular}

Sumber: Data diolah, 2019

Nilai Prob. $\mathrm{F}(2,12)$ sebesar 0.4140 dapat juga disebut sebagai nilai probabilitas $\mathrm{F}$ hitung. Nilai Prob. F hitung lebih besar dari tingkat alpha 0,05 (5\%) sehingga, berdasarkan uji hipotesis, $\mathrm{H}_{0}$ diterima yang artinya tidak terjadi autokorelasi. Sebaliknya, apabila nilai Prob. F hitung lebih kecil dari 0,05 maka dapat disimpulkan terjadi autokorelasi.

Selain menggunakan LM Test, dapat juga menggunakan Durbin-Watson. Nilai Durbin-Watson sudah tertampil pada jendela Equation: Persamaan (tabel 5.8) yang mana nilainya 1.919594. Nilai ini biasa disebut dengan DW hitung. Nilai ini akan dibandingkan dengan kriteria penerimaan atau penolakan yang akan dibuat dengan nilai $\mathrm{dL}$ dan dU ditentukan berdasarkan jumlah variabel bebas dalam model regresi (k) dan jumlah sampelnya (n). Nilai dL dan dU dapat dilihat pada Tabel DW dengan tingkat signifikansi (error) 5\% $(\alpha=0,05)$. Jumlah variabel bebas : $\mathrm{k}=3$ Jumlah sampel $: \mathrm{n}=18$

Tabel Durbin-Watson menunjukkan bahwa nilai $\mathrm{dL}=0.9331$ dan nilai $\mathrm{dU}$ $=1.6961$ sehingga dapat ditentukan kriteria terjadi atau tidaknya autokorelasi seperti terlihat pada gambar di bawah ini :

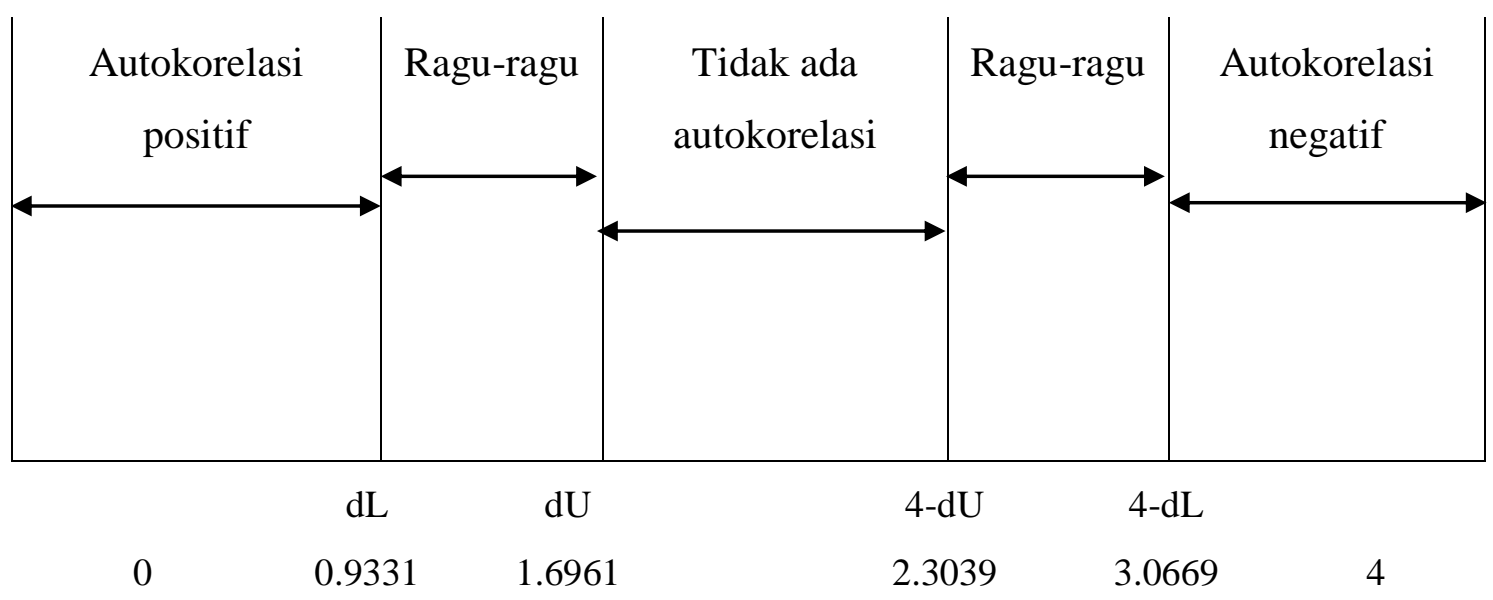

Gambar 2. Uji autokorelasi Durbin Watson 
Nilai DW hitung sebesar 1.919594 lebih besar dari 1.6961 dan lebih kecil dari 2.30996 yang artinya berada pada daerah tidak ada autokorelasi. Hasil pengujian autokorelasi dengan menggunakan dua pendekatan memberikan hasil yang sama, sehingga dapat disimpulkan bahwa bahwa dalam model regresi linier yang diajukan tidak mengandung autokorelasi. Artinya pemenuhan asumsi klasik model regresi linier telah dilakukan.

\section{Uji heteroskedastisitas}

Uji Heteroskedastisitas digunakan untuk menguji apakah pada model regresi terjadi ketidaksamaan varian dari residual satu pengamatan ke pengamatan lainnya. Jika varian tersebut tetap maka disebut homoskedastisitas, dan jika berbeda disebut heteroskedastisitas. Model regresi yang baik adalah yang homoskedastisitas atau tidak terjadi heteroskedastisitas.

Tabel 11. Hasil uji heteroskedastisitas

\begin{tabular}{lcll}
\hline Heteroskedasticity Test: Breusch-Pagan-Godfrey & \\
\hline F-statistic & 0.349414 & Prob. F(3,14) & 0.7902 \\
Obs*R-squared & 1.253857 & Prob. Chi-Square(3) & 0.7401 \\
Scaled explained & 0.373900 & Prob. Chi-Square(3) & 0.9456 \\
SS & & & \\
\hline
\end{tabular}

Sumber: Data diolah, 2019

Keputusan terjadi atau tidaknya heteroskedastisitas pada model regresi linier adalah dengan melihat Nilai Prob. F-statistic (F hitung). Apabila nilai Prob. F hitung lebih besar dari tingkat alpha $0,05(5 \%)$ maka $\mathrm{H} 0$ diterima yang artinya tidak terjadi heteroskedastisitas, sedangkan apabila nilai Prob. F hitung lebih kecil dari dari tingkat alpha $0,05(5 \%)$ maka $\mathrm{H}_{0}$ ditolak yang artinya terjadi heteroskedastisitas. Nilai Prob. $\mathrm{F}$ hitung sebesar 0.7902 lebih besar dari tingkat alpha 0,05 (5\%) sehingga, berdasarkan uji hipotesis, $\mathrm{H}_{0}$ diterima yang artinya tidak terjadi heteroskedastisitas.

\section{Analisa ekonomi}

Selama periode penelitian tahun 2000-2017 dapat dijelaskan bahwa pertumbuhan ekonomi di Kabupaten Sarolangun dipengaruhi tenaga kerja, PMDN,dan pengeluaran pemerintah. Berikut ini interpretasi koefisien regresi variabel- variabel yang ada dalam model regresi:

\section{Tenaga kerja}

Dengan koefisien regresi tenaga kerja adalah sebesar 3.8605 sehingga dapat diartikan jika tenaga kerja mengalami kenaikan sebesar 1 persen maka perumbuhan ekonomi akan naik sebesar 3.8605 persen. Dengan semakin meningkatnya jumlah tenaga kerja, maka akan dapat mendorong pertumbuhan ekonomi di Kabupaten Sarolangun.

\section{Penanaman modal dalam negeri}

Dengan koefisien regresi dari variabel PMDN adalah sebesar 1.631326 yang artinya jika PMDN mengalami kenaikan sebesar 1 persen maka pertumbuhan ekonomi 
akan naik 1.631326 persen. Dengan semakin banyaknya investasi PMDN di Kabupaten Sarolangun maka akan mendorong pertumbuhan ekonomi Kabupaten Sarolangun.

\section{Pengeluaran pemerintah}

Dengan koefisien regresi pengeluaran pemerintah berpengaruh signifikan dan berhubungan positif terhadap pertumbuhan ekonomi di Kabupaten Sarolangun. Dengan nilai koefisien sebesar 2.916796, yang artinya jika pengeluaran pemerintah mengalami kenaikan sebesar 1 persen maka pertumbuhan ekonomi akan naik 2.916796 persen.

\section{Implikasi hasil penelitian}

Hasil penelitian ini memberikan beberapa hasil empiris mengenai faktor-faktor yang mempengaruhi pertumbuhan ekonomi di Kabupaten Sarolangun. Dari hasil analisis ini menunjukkan sebenarnya pertumbuhan ekonomi di Kabupaten Sarolangun itu masih sangat tergantung dari besarnya jumlah investasi yang masuk ke Kabupaten Sarolangun khususnya PMDN, karena dengan semakin meningkatnya jumlah PMDN yang masuk ke Kabupaten Sarolangun ini berarti dapat digunakan sebagai modal untuk menggerakkan perekonomian di Kabupaten Sarolangun. Agar investasi tetap masuk ke Kabupaten Sarolangun, maka pemerintah Kabupaten Sarolangun harus mampu menciptakan iklim investasi yang kondusif, bisa menarik investor, dan bisa memberikan kemudahan-kemudahan agar investor bisa masuk ke Kabupaten Sarolangun.

Selain itu dengan dukungan jumlah tenaga kerja yang semakin meningkat akan dapat mendorong dan mempercepat pelaksanaan pembangunan di berbagai sektor di Kabupaten Sarolangun. Dengan semakin meningkatnya jumlah tenaga kerja yang berkualitas yang bekerja, maka akan dapat mendorong percepatan pembangunan. Keberhasilan pembangunan khususnya di bidang ekonomi akan menyebabkan meningkatnya pertumbuhan ekonomi. Meningkatnya pertumbuhan ekonomi akan menyebabkan meningkatnya jumlah tenaga kerja yang terserap untuk bekerja di berbagai sektor di Kabupaten Sarolangun. Meningkatnya pertumbuhan ekonomi juga harus diikuti dengan pertambahan jumlah penyediaan lapangan kerja. Bertambahnya jumlah lapangan kerja akan menyebabkan bertambahnya jumlah tenaga kerja yang terserap dalam pekerjaan tersebut. Untuk penyediaan lapangan kerja dan lapangan berusaha dibutuhkan sejumlah anggaran baik yang berasal dari dalam negeri maupun dari luar negeri. Dengan bertambahnya jumlah investasi yang masuk ke Kabupaten Sarolangun dan jumlahnya meningkat dari tahun ke tahun akan mendukung penyediaan jumlah lapangan kerja dan lapangan berusaha, dan ini akan dapat membantu mengurangi jumlah pengangguran di Kabupaten Sarolangun. Berkurangnya jumlah pengangguran dan diikuti dengan peningkatan pendapatan masyarakat akan dapat meningkatkan kesejahteraan masyarakat.

Dukungan pengeluaran pemerintah dalam kegiatan pembangunan di Kabupaten Sarolangun dari tahun ke tahun semakin meningkat. Peningkatan pengeluaran pemerintah ini sebanding dengan hasil pembangunan yang dirasakan oleh masyarakat Kabupaten Sarolangun. Ini berarti bahwa dengan meningkatnya pengeluaran pemerintah maka akan menyebabkan meningkatnya pertumbuhan ekonomi. Keberhasilan pembangunan khususnya di bidang ekonomi akan menyebabkan meningkatnya pertumbuhan ekonomi. Penanaman Modal Dalam Negeri (PMDN) berpengaruh positif terhadap pertumbuhan ekonomi. Hal itu sebenarnya baik pula untuk 
perekonomian suatu daerah karena itu artinya adanya penanaman modal dalam negeri sudah bermanfaat dan mampu membawa dampak yang positif bagi suatu daerah.

Pengeluaran pemerintah juga berpengaruh positif terhadap pertumbuhan ekonomi itu juga merupakan dampak yang baik dari adanya pengeluaran pemerintah. Karena dengan begitu pengeluaran pemerintah tidak serta merta hanya dilakukan untuk belanja yang tidak ada manfaatnya akan tetapi justru dapat meningkatkan pertumbuhan ekonomi.

\section{KESIMPULAN DAN SARAN}

\section{Kesimpulan}

Perkembangan rata-rata tenaga kerja tahun 2000-2017 adalah 3,20 persen per tahun, PMDN Kabupaten Sarolangun cenderung berfluktuasi dengan rata-rata perkembangan sebesar 9,35 persen per tahun, pengeluaran pemerintah juga mengalami fluktuasi tetapi cenderung mengalami kenaikan dengan rata-rata perkembangan sebesar 14,75 persen per tahun dan pertumbuhan ekonomi Kabupaten Sarolangun juga mengalami fluktuasi dengan rata-rata perkembangan sebesar 6,56 persen per tahun. Hasil regresi menunjukan bahwa variabel tenaga kerja, PMDN dan pengeluaran pemerintah berpengaruh signifikan terhadap pertumbuhan ekonomi di Kabupaten Sarolangun.

\section{Saran}

Dalam meningkatkan tenaga kerja, investasi PMDN, pengeluaran pemerintah dan pertumbuhan ekonomi, pemerintah harus memperbaiki sarana dan prasarana sehingga dapat mendorong peningkatan investasi terutama sarana transportasi baik di darat, yang menunjang untuk mendirikan usaha-usaha baru di Kabupaten Sarolangun. Tenaga kerja yang semakin meningkat di Kabupaten Sarolangun juga turut mendorong naiknya pertumbuhan ekonomi sehingga diharapkan pemerintah dapat meningkatkannya dengan cara mendorong peningkatan investasi.

Perlu adanya peningkatan kualitas SDM yang akan memasuki pasar kerja, agar mereka mudah dan dapat digunakan oleh perusahaan/pengguna tenaga kerja. Perlu adanya kebijakan yang membantu dan memberikan kemudahan kepada para investor untuk masuk ke Kabupaten Sarolangun,. Dengan meningkatnya pengeluaran pemerintah, maka akan meningkat pula pertumbuhan ekonomi, ini bukan berarti bahwa pengeluaran pemerintah harus ditingkatkan secara besar-besaran tanpa arah yang jelas, tetapi peningkatan pengeluaran pemerintah itu harus diimbangi dengan keberhasilan pembangunan di berbagai sektor atau bidang.

\section{DAFTAR PUSTAKA}

Ardian, Sutawijaya; \& Zulfakmi. (2007). Pengaruh ekspor dan investasi terhadap pertumbuhan ekonomi Indonesia Tahun 1980-2006. Jurnal Organisasi dan Manajemen, 8(2).

Badan Pusat Statistik. (2000-2018). Sarolangun dalam Angka. https://www.bps.go.id. 03 April 2019 Pukul 09:00. 
Damanik, AM; Z Zulgani, \& R Rosmeli. (2018).Faktor-faktor yang mempengaruhi ketimpangan pendapatan melalui pertumbuhan ekonomi di Provinsi Jambi, $e$ Jurnal Perspektif Ekonomi dan Pembangunan Daerah, 7 (1), 15-25

Ghozali, Imam. (2011). Aplikasi analisis multivariate dengan program SPSS. Buku. Universitas Diponegoro: Semarang

Gujarati. Damodar. (2003). Economectric. Erlangga. Jakarta.

Harjono. D.K.(2007). Hukum penanaman modal. Raja Grafindo Persada: Jakarta.

Mustika,C; E Achmad; \& E Umiyati. (2018). Dampak ekspor ke Jepang dan investasi asing terhadap pendapatan perkapita masyarakat di Indonesia, Jurnal Paradigma Ekonomika, 13 (2), 47-54

Partadiredja, Ace. (2004). Ekonomika. Buku. UI Press: Jakarta.

Rahardja, Pratama; \& Mandala Manurung. (2002). Pengantar ilmu ekonomi. Buku. Penerbit FEUI: Jakarta.

Sukirno, Sadono. (2004). Teori pengantar makro ekonomi. Edisi Ketiga. Buku. Penerbit PT. Raja Grafindo Persada: Jakarta.

Sukirno, Sadono. (2006). Ekonomi pembangunan: Proses, Masalah, dan Dasar Kebijakan Edisi Kedua. Buku. Penerbit Kencana: Jakarta.

Sunyoto, Suyanto. (2011). Analisis regresi untuk uji hipotesis. Caps: Yogyakarta

Suparmoko. (2000). Keuangan negara dalam teori dan praktek. Buku. BPFE. Yogyakarta.

Tambunan, Tulus. (2004). Perekonomian Indonesia. Buku. Ghalia Indonesia. Jakarta.

Todaro. (2000). Pembangunan ekonomi di dunia ketiga. Erlangga. Edisi Bahasa Indonesia. Buku II. Buku. Erlangga: Jakarta.

Widarjono, Agus. (2009). Ekonometrika pengantar dan aplikasi. Edisi Ketiga. Penerbit Ekonosia: Yogyakarta.

Zamzami,Z; \& D Hastuti. (2018). Determinan penerimaan daerah dan pertumbuhan ekonomi terhadap pengembangan ekonomi kreatif di Provinsi Jambi. Jurnal Paradigma Ekonomika, 13 (1), 37-45 